\title{
PERCEPTION OF ALUMNI ON HIGHER LEARNING EDUCATION EFFICACY IN BUTEMBO, DEMOCRATIC REPUBLIC OF CONGO
}

\author{
Matsundo KS* \\ Département de Géographie et Gestion de l'Environnement, Section Sciences Exactes, \\ Institut Supérieur Pédagogique de Muhangi à Butembo, DRC
}

\begin{abstract}
This study analyzed the alumni perception of the educational efficacy of higher learning institutions in Butembo. A purposive sampling technique was used, and 281 respondents answered the survey of the study. Information was organized in tables for good interpretation. Results show that there are 31 Institutions for higher learning education in Butembo. Among them, InstitutSupérieurPédagogique de Muhangi (ISP-M) had 20.3\% alumni among respondents, $12.3 \%$ were from InstitutSupérieur des Techniques Médicales (ISTM) Butembo, $11.0 \%$ of them from the Universté de l'Assomption au Congo (UAC), 9.6\% from UniversitéCatholique du Graben (UCG), and 7.5\% from UniversitéOfficielle de Ruwenzori. Findings reveal that graduates strongly agree that what they learned in college helps them in their profession. They agree that there are signs of higher learning institutions and universities' success in Butembo and surrounding, agreed to be satisfied by the training received. The findings show that workforce value is positively and significantly correlated with alumni's function $(\mathrm{r}=.883)$, with the education level ( $\mathrm{r}=.806)$, with age $(\mathrm{r}=.745)$, current occupation $(\mathrm{r}=.718)$, gender of alumni $(\mathrm{r}=.598)$, operation activities ( $\mathrm{r}=.549)$, and with the hierarchical position in the company $(\mathrm{r}=.465)$. Based on the findings, it was recommended that university students take their choice of orientation seriously for future education sustainability, career development, and community development by putting into practice what they learned during training.
\end{abstract}

Keywords: Perception of alumni, alumni, education efficacy, higher learning Institutions, Butembo

\section{Introduction}

Education is an area of community facility facing increasing inquiry and criticism for its low quality and productivity associated with educational effectiveness that defines its workforce value. According to Darra (2006), educators are being called on to function effectively and efficiently. They are expected to adopt policies and methods that will permit even greater productivity. Improvements in the workforce's educational attainment have been a consistently important source of gain in labor productivity.

Analyzing the educational effectiveness of higher learning institutions and workforce value is a timely investigation. Like other countries globally, the Democratic Republic of Congo (DRC) relies on education in general and university education in particular. This is for the development by constructing a powerful human capital and capacity building to address human development 
inequalities in achieving the 2030 Agenda for Sustainable Development (The Human Development Report, 2019).

Darra (2006) described that measuring effectiveness can be difficult, though not impossible. One way to measure effectiveness is to assess the community standards of other institutions of higher learning in terms of the number of graduates who find a job within three months of graduation, students' accomplishments, such as the number of students taking a class that requires relatively advanced work, such as technical research paper. The number of graduates receiving advanced degrees is an alternative measure, and client satisfaction is the third avenue to measure effectiveness.

In the DRC, the national education framework law of 11 February 2014 clarifies the mission of higher education in these terms in article 88: to train high-level executives, specialized for the exercise of a profession, especially in priority sectors such as education, health, agriculture, technology, management, and the arts. Article 95 hammers home by specifying that the mission of university education is to: (1) train design frameworks capable of contributing to the qualitative transformation of society; (2) to contribute to the evolution of science by organizing fundamental and applied research-oriented towards development; (3) ensure and promote the dissemination of research results (KABANGE, 2014).

University education is recent in Butembo and its surroundings because the oldest universities, such as the Université Catholique du Graben, date from the 80s. However, there is a proliferation of institutions. This arouses the researcher's thirstto know whether these institutions are correctly training students according to their agreements, given the importance of education effectiveness. Recognizing that little to no research has been conducted within higher education and employment in the DRC during the last two decades, this research will clarify the effect of higher learning institutions' educational effectiveness on the workforce's value in Butembo city and surroundings. My hypothesis is that the university education of Butembo and its surroundings is not satisfactory in the eyes of alumni because the number of students are generally decreasing in the universities, while the growth of the population is visibly galloping in the region.

My objective is to elucidate the appreciation of Butembo university alumni on the training they undergo.

\section{Review of Related Literature}

OECD (2005) described that upper secondary graduation rates are higher among young women than young men in most OECD countries where female graduates rates exceed male rates. Advanced research degrees were the only levels in which men continue to dominate numerically. Concerning mathematical literacy, significant differences are found in favor of male students in about half of the countries included in the PISA study and about one-third of those included in TIMSS (OECD, 2004).

According to AfDB et al. (2012), the transition of new graduate students from universities to employment in the Democratic Republic of Congo has been a significant topic for debate over the last twenty years. Even though the demand for access to higher education is very high, results revealed that the current curriculum and policies have inherent inefficiencies that do not provide new graduates with sufficient skills to move into and be productive in the labor market easily. For Etshim (2017), the 
need for collaboration between higher education institutions and employers to design effective curricula and build up an educational environment that genuinely benefits current students and their future employers in the DRC.

Education plays a central role in preparing youths to enter the labor market and equipping them with the skills needed to engage in lifelong learning experiences. Referring to the labor market requirements and the new industrial world, the educational system must be practical to boost industries and improve the population's socio-economic welfare (AfDB et al., 2012).

Tafazoli (2019) treated attitude towards computer-assisted language learning: do gender, age, and educational level matter? The purpose of the present cross-cultural study was to explore the relationships of second and foreign language teachers' and students' attitudes towards ComputerAssisted Language Learning (CALL) in terms of their gender, age group, and educational level two countries, Spain and Iran. The study was based on a sample of 318 language teachers and 307 language students in Iran and Spain. Data collection was carried out through two online questionnaires (108 items) for both teachers and students. To make a sound decision, the researchers decided to utilize the Delphi methodology, which was originally established to diagnose the beneficiary of technologies. The data analysis phase, descriptive, t-test, and one-way ANOVA analyses were performed to find the answers to the research questions. The study's findings revealed no difference between the attitudes of Iranian and Spanish towards CALL in terms of gender, age, and educational matter.

Berger \& Fisher (2013) argued that it is fundamental to offering access to high-quality education and related supports. Particularly for young people who today lack such access, it will expand economic opportunity for those individuals and likely do more to strengthen the overall state economy than anything else a state government can do to maintain a workforce for quality services.

The practical education system ensures workforce production is socially responsible for the economic growth of human development (Modisaotsile, 2012). Darra (2006) stated that the modern notion of productivity includes both organizational efficiency and effectiveness. In education, outputs are principally represented by teaching, outcomes by learning. Effectiveness is a measure of the development of an operational unit like a school or a university department. It is a measure of how well a working team was able to accomplish its objective.

Perrenoud (2005) found that primary or compulsory education objectives are reformulated in terms of skills and that claiming to target skills means being able to name them, therefore identifying categories of situations they are supposed to allow to master conceptually and practically. President of the Royal Bank of Canada (1956), responding to a schoolgirl who wanted to know, what is education for? In showing overall effectiveness, he alluded to the importance of the general culture that a worker must have. According to the senior official, a worker who has become accustomed to school can learn more easily in the factory. He knows more quickly not only the "methods" but also the "reasons" for his task. He understands his problems better and faster.

Neumann (2017) studied the implications for the educational effectiveness of online master's degree programs. The study integrated the Spiral Curriculum approach into the Robust Learning Model as part of a continuous improvement process designed to improve educational effectiveness. It then assessed the differences between the initial and integrated models and the predictability of the first 
course in the integrated learning model on a wide range of educational effectiveness indicators for online master degree programs. The study validated meaningful improvement in educational effectiveness. The importance of the first course's predictors in predicting and explaining the various degree program educational effectiveness indicators was also very instrumental. The theoretical and practical implications of the study's findings for online faculty, university administrators, and policymakers were examined.

According to JAFARI B. et al. (2019), the educational effort and the quality of Moroccan graduates are subject to several evaluations, in this sense, they judged after a review of the main educational indicators that the quality of training and individual effectiveness are the main barometers of appreciation of the quality of each student. However, these measurement parameters in themselves do not provide an overall visual summary of the quality of higher education in general and graduates in particular. As a result, strategic marketing tools present themselves as the coveted solution to this problem. Inspired by the matrices of the management of the business portfolio, in particular the BCG matrix, they have built two matrices: the first is dedicated to academic institutions and the other to graduates from these institutions, in order to classify them according to their level of quality.

The analyses by Bonvin F. (2019) highlight a national political discourse focused on the existing quality of the Swiss education system, in order to establish the leading position at the international level rather than a real discussion on equity issues, the definition and implementation of which are left to the cantons. KAMAL ZOUHRI et al., (2016) proposed new quantitative indicators for evaluating the effectiveness of open access higher education, which are suitable for the new university system (LMD system), in order to obtain clearer and more precise results of the quality of the university system in Moroco

Drawing inspiration from the deactivate portfolio management matrices, in particular the BCG matrix, they built two matrices: the first is dedicated to universities and the other to graduates from these institutions, in order to classify them according to their quality level. Creemers (2015) scrutinized the process-product research: a cornerstone in educational effectiveness research. This article links the contribution of process-product studies in developing the theoretical framework of educational effectiveness by pointing out the importance of teacher behavior in the classroom. Jere Brophy's role in this evolving research is described within the various phases of teacher effectiveness research. Process-product studies revealed the importance of moving from investigating teachers' characteristics to identifying characteristics of effective teaching practices. Research on factors other than teacher behavior, conducted during the last three decades, has not generated empirical support to show that these factors directly affect student achievement. Only a few of them reveal indirect effects by influencing teacher behavior in the classroom. It is also argued that current models of educational effectiveness research drawn from Brophy's research further the development of constructs generated through the process and product studies. Additionally, the dynamic model of educational effectiveness shows how the original ideas in the process-product studies were considered effective and expanding them further by introducing a multidimensional approach to measure the impact of these factors and grouping of factors on student learning outcomes. 


\section{Methodology}

To have the opinions of the Alumni of the University Education of Butembo and its surroundings, I designed a survey questionnaire that I submitted to a sample of 281 respondents encountered mostly in employment companies. This study was based on a descriptive-correlational research design. The descriptive research design was used for processing with logical interpretation using descriptive statistics expressed as frequencies, mean, and standard deviation across the data collected. On the other hand, the correlation part involves measuring the relevant variables evaluated for the relationship between these variables using Pearson's correlation and multiple regression to determine which factor has a more substantial influence on the dependent variables. The results design established the relationship between sociodemographic profile and membership value on the one hand.

And on the other hand, facilities, faculty and staff, alumni, school programs, and graduates value workplace value. Correlation indicated whether there is a positive correlation or a negative correlation. Multiple regression helped determine which factors most affect the value of the workforce.

Respondents provided answers to questions with a Likert scale using the following measurement 5 $=$ Strongly agree, 4=Agree, 3=Partially Agree, 2=Disagree, and 1= Strongly Disagree. Different statistical tools were used for this study for the data analysis methods: frequency counts, percentage distribution, mean and standard deviation used for sociodemographic characteristics. Likewise, descriptive statistics such as percentage, frequency, mean and standard deviation were used to analyze the objectives of this study.

\section{Results and Discussion}

This section presents and discusses the results of this study. It covers the sociodemographic profile of respondents; their identity concerning their training institutions, including the institution's name, the year of graduation, its rank in the company in which it is employed, its training stream, and its current occupation. The study assesses the evaluation of the training received from universities and how alumni are appreciated for their educational background in Butembo city and its surroundings.

\section{Sociodemographic Profile}

The sociodemographic profile presented in Table 1 includes gender, age, and the highest level of education.

Table 1: Sociodemographic Profile of Respondents

SOCIODEMOGRAPHIC PROFILE FREQUENCY $(\mathrm{N}=281) \quad$ PERCENTAGE

\begin{tabular}{lll}
\hline Sex & & \\
Male & 206 & 73.3 \\
Female & 75 & 26.7 \\
Age & & \\
$21-30$ years old & 84 & 29.9
\end{tabular}




$\begin{array}{lll}\text { 31-40 years old } & 128 & 45.6 \\ 41-50 \text { years old } & 54 & 19.2 \\ 51-60 \text { years old } & 15 & 5.3 \\ 61 \text { and above year sold } & 0 & 0.0 \\ & \text { Mean: 35.5; SD: 8.4 } \\ \text { Educational Attainment } & & \\ \text { Graduate } & 164 & 58.4 \\ \text { Masters } & 114 & 40.6 \\ \text { DEA/DSS } & 2 & 0.7 \\ \text { PhD } & 1 & 0.4\end{array}$

Age

Results in Table 1 show that $45.6 \%$ of respondents were aged between $31-40$ years, $29.9 \%$ were aged between 21-30 years, 19.2\%, 5,3\% were aged between 51-60 years. $0 \%$ were aged 61 and above years old. The results were aged on average of 36 years old.

Sex

The majority (73.3\%) of graduates in business representatives and from the institutions surveyed were men, while women represented $26.7 \%$ in Butembo and surrounding graduates. These show that men are more likely to attend and reach university level and higher corporate positions than women. Kasai (1998) supports the findings by pointed out that female students represented less than $20 \%$ of the total workforce with an annual average of $11 \%$ at the undergraduate level, while it did not reach $9 \%$ at the secondary level at the Bukavu Higher Educational Institute (ISP Bukavu). This is in line with the French Republic's Ministry of Higher Education and Research (2013) study that overall, the professional integration of higher education graduates three years after their studies is better for men. Nearly two-thirds of men are employed three years later in executive or intermediate occupations, less than half of women. It is only similar to researcher observations showing that in some jobs that do not require any level of education, women seem not to be at the forefront in our country. Also, MATUMAINI (2015) found that most of those running positions in for businesses and universities in Butembo are men; only the women appear in the chain only at the marketing of finished products.

\section{Educational Attainment}

Findings indicate that more than half (58.4\%) were graduates, $40.6 \%$ of them with Masters, and only $1.1 \%$ had $\mathrm{PhD}$ level. Indeed, the doctoral cycle is only at its embryonic stage in the region.

\section{Alumni Appreciation of Higher and University Education}

This section revolves around the appreciation of university education by those who have undergone the training. It was interested to have their identity in terms of training from institutions, concerns in their careers, the year of graduation, the course of training, and finally, their current occupations. Then there is an investigation for the training received concerning the reality of the knowledge required in the job, the consistency of the job with the course followed, the signs of success and those 
of failure of university education in Butembo, the existence of companies created by graduates. These channels have an easy flow on the job market and the overall appreciation of universities.

\section{Represented Institutions}

Table 2 lists 31 Institutions, the most represented of which are the InstitutSupérieurPédagogiqueMuhangi (ISP-M) with $20.3 \%$ of respondents, InstitutSupérieur des Techniques Médicales (ISTM) of Butembo with $12.1 \%$ respondents, the Universté de l'Assomption au Congo (UAC) with (11.0\%), UniversitéCatholique du Graben (UCG) with $9.6 \%$ of respondents, UniversitéOfficielle de Ruwenzori with $7.5 \%$ of respondents, and others follow as it is indicated in table 8; but also on the map by following this link for location: (http://umap.openstreetmap.fr/fr/map/map-of-cce-esu-butembo-and-

surroundings_618289\#13/0.1348/29.2933)

Table 2: Surveyed Institutions

\begin{tabular}{|c|c|c|c|}
\hline No & INSTITUTION & EFFECTIF & PERCENTAGE \\
\hline 1 & ISP - M & 57 & $20,28 \%$ \\
\hline 2 & ISTM Butembo & 34 & $12,10 \%$ \\
\hline 3 & UAC (ISEAB) & 31 & $11,03 \%$ \\
\hline 4 & UCG & 27 & $9,61 \%$ \\
\hline 5 & UOR & 21 & $7,47 \%$ \\
\hline 6 & ISEAVF & 10 & $3,56 \%$ \\
\hline 7 & ISDR KITSOMBIRO & 9 & $3,20 \%$ \\
\hline 8 & ISP Masereka & 9 & $3,20 \%$ \\
\hline 9 & IBTP BUTEMBO & 8 & $2,85 \%$ \\
\hline 10 & ULPGL & 8 & $2,85 \%$ \\
\hline 11 & ISC Butembo & 8 & $2,85 \%$ \\
\hline 12 & UNILUK & 8 & $2,85 \%$ \\
\hline 13 & ULD & 7 & $2,49 \%$ \\
\hline 14 & ISAM L & 5 & $1,78 \%$ \\
\hline 15 & ISPT M & 5 & $1,78 \%$ \\
\hline 16 & UNIC & 3 & $1,07 \%$ \\
\hline 17 & ISSC-M & 3 & $1,07 \%$ \\
\hline 18 & UDGB & 3 & $1,07 \%$ \\
\hline 19 & UCNDKA & 2 & $0,71 \%$ \\
\hline 20 & ISAD Goma & 2 & $0,71 \%$ \\
\hline 21 & UNIFA & 2 & $0,71 \%$ \\
\hline 22 & BIU & 1 & $0,36 \%$ \\
\hline 23 & ENACTI & 1 & $0,36 \%$ \\
\hline 24 & Institut de Développement & 1 & $0,36 \%$ \\
\hline 25 & ISP Butembo & 1 & $0,36 \%$ \\
\hline 26 & ISP Kirumba & 1 & $0,36 \%$ \\
\hline 27 & ISTDM & 1 & $0,36 \%$ \\
\hline 28 & ISUPA & 1 & $0,36 \%$ \\
\hline 29 & UCV Butembo & 1 & $0,36 \%$ \\
\hline 30 & UNIDEC & 1 & $0,36 \%$ \\
\hline
\end{tabular}


$\begin{array}{llll}31 & \text { UTAB } & 1 & 0,36 \%\end{array}$

\section{Hierarchical positions in the company}

Table 3 shows that the majority (77.2\%) of respondents were executive officers, $20.6 \%$ were management staff, and $2.1 \% \%$ of them were not yet employed. This situation shows that academics occupy the highest ranks in companies. However, according to the personal testimonies of some interviewees, occupying these honorable positions does not necessarily have an impact on income. When they got into other operations under certain circumstances, they earned more than they earn while an executive officer. This was the case with an undergraduate alumnus who experimented with taking babysitting training after missing out on employment in his field of study. After this training, he also did not find a job. He joined the brick press workers, from where he got great financial relief.

Table3: Hierarchical positions in the company

\begin{tabular}{lll} 
Position & Effective & Percentage \\
\hline Executiveofficer & 217 & 77.2 \\
Management agent & 58 & 20.6 \\
Worker & 0 & 0.0 \\
Unemployed & 6 & 2.1 \\
\hline
\end{tabular}

\section{Current occupations of graduates}

Results in table 4 reveal that more than half $(53.41 \%)$ of respondents were in the area of education (39.5\% of the teachers), $19.7 \%$ of the respondents were working in companies (3.2\% of them were accountants, and $1.4 \%$ of them were humanitarian), $15.2 \%$ of them were in the health sector $(5.0 \%$ of them were nurses), $8.3 \%$ of them were in area of communication ( $6.1 \%$ were journalists), $1.5 \%$ were in the area of financial institutions and $0.4 \%$ respectively were representatives from Agricultural firm and churches. The results show that the main employment sector in the region today is teaching. This is not very different from the situation found by Perrichot (2018), who listed the sectors that recruited more in 2018 in France that included services such as health, hotel and catering, construction, commerce, education, communication, transport, and logistics.

Table 4: Current occupations of graduates

\begin{tabular}{lll}
\hline Occupation & Frequency & Percentage \\
\hline Education services & 141 & 53.41 \\
Company business & 52 & 19.70 \\
Health services & 40 & 15.15 \\
Communication and media & 22 & 8.33 \\
Financial institution & 4 & 1.52 \\
Unemployed & 3 & 1.14 \\
\hline Agriculture & 1 & 0.38 \\
Church & 1 & 0.38 \\
\hline
\end{tabular}




\section{Evaluation of the training received}

The results in table 5 show the perception of self-satisfaction among Butembo university graduates. Findings indicate that graduates strongly agree that what they learned in college help them in their professions with the mean of 4.23 , they agree (mean=3.67) that there are signs of higher learning institution and universities success in Butembo and surrounding, they agree (3.57) that Alumni who studied in Butembo and surroundings do not have jobs in their fields of training; they agreefor the satisfaction of the training received with an average mean of 3.49. Respondents partially agree that there are businesses created by graduates with a mean of 3.38 and partially agree that there are signs that show the failure of university education in Butembo and its surroundings with a mean of 2.67. This average is consistent with what these respondents give as an overall assessment of university education in Butembo and Surroundings, presenting a numerical average of 6.42 , giving the grade good with a standard deviation of 1.08 .

Table 5: Evaluation of the Training Received

\begin{tabular}{llll}
\hline $\begin{array}{l}\text { Parameters on the Evaluation of the } \\
\text { Training Received }\end{array}$ & Mean & Sd & Verbal interpretation \\
\hline $\begin{array}{l}\text { Students from college and universities in Butembo are well } \\
\text { appreciated in their workplace }\end{array}$ & 3.49 & 0.03 & Agree \\
$\begin{array}{l}\text { I'm practicing what I learned in college for my } \\
\text { professionals }\end{array}$ & 4.23 & 0.05 & Strongly Agree \\
$\begin{array}{l}\text { Alumni who studied in Butembo and surroundings do not } \\
\text { have jobs in their fields of training }\end{array}$ & 3.57 & 0.07 & Agree \\
$\begin{array}{l}\text { There are signs of the success of ESU Butembo. } \\
\begin{array}{l}\text { On the other hand, there are signs that ESU Butembo has } \\
\text { failed. }\end{array}\end{array}$ & 3.62 & 0.06 & Agree \\
\hline
\end{tabular}

Legend: $4.2-5.0=$ Strongly Agree

3.4-4.1= Agree

2.6-3.3= Partially agree

$1.8-2.5=$ Disagree

$1-1.7=$ Strongly Disagree,

\section{Relationship Between Socio-Demographic Characteristics and Workforce Value of Alumni}

This section shows the sociodemographic characteristics, internal efficiency factors, and workforce value analysis from the study. The Pearson correlation was used to analyze the data.

The results in Table 6 reveal that there are relationships between workforce value and sociodemographic characteristics of alumni. The findings show that the workforce value is positively and significantly correlated with the function of alumni ( $\mathrm{r}=.883)$, with the education level $(\mathrm{r}=.806)$, with age ( $\mathrm{r}=.745)$, current occupation ( $\mathrm{r}=.718)$, sex of alumni $(\mathrm{r}=.598)$, operation activities $(\mathrm{r}=.549)$, hierarchical position in the company $(\mathrm{r}=.465)$, and position in the company $(\mathrm{r}=.307)$. This means that the sociodemographic characteristics go along with the workforce value of employees. Either male or female, young or old, as long as you are educated, have a position, and implement activities in the company, everyone's work is proved valuable. This implies that alumni from universities in Butembo and their surroundings positively impact the companies' operations. For his part, Kivete (2013), in his 
reflection on the relevance of higher and university education in Butembo and its Surroundings, found that there is a negative correlation between graduates in economics and the urban business development in Butembo.

Table 6: Relationship Between Socio-demographic Characteristics and Workforce Value

\begin{tabular}{ll}
\hline PARAMETERS & $\begin{array}{l}\text { Workforce value } \\
\text { settings }\end{array}$ \\
\hline Sex for graduates & $.598^{* *}$ \\
Age for graduates & $.745^{* *}$ \\
Education level for graduates & $.806^{* *}$ \\
Position in the company & $.307^{* *}$ \\
Hierarchical positions in the company & $.465^{* *}$ \\
Current occupation of alumni & $.718^{* *}$ \\
Function in the structure by graduates & $.883^{* *}$ \\
Operation activities of respondents & $.549^{* *}$ \\
\hline & \\
**. Correlation is significant at the 0.01 level (2-tailed). & \\
$*$. Correlation is significant at the 0.05 level (2-tailed).
\end{tabular}

\section{Conclusion}

Frequented Institutions were 31 Institutions, and the most represented of which are the InstitutSupérieurPédagogiqueMuhangi (ISP-M) with $20.3 \%$ of respondents, InstitutSupérieur des Techniques Médicales (ISTM) of Butembo with $12.1 \%$ respondents, the Universté de l'Assomption au Congo (UAC) with (11.0\%), UniversitéCatholique du Graben (UCG) with 9.6\% of respondents, UniversitéOfficielle de Ruwenzori with $7.5 \%$ of respondents.

Hierarchical positions in the company findings show that the majority (77.2\%) of respondents were executive officers, $20.6 \%$ were management staff, and $2.1 \% \%$ of them were not yet employed. This situation shows that academics occupy the highest ranks in companies. Current occupations of graduates results indicate that more than half $(53.41 \%)$ of respondents were in the area of education (39.5\% of the teachers), $19.7 \%$ of the respondents were working in companies (3.2\% of them were accountants, and $1.4 \%$ of them were humanitarian), $15.2 \%$ of them were in the health sector $(5.0 \%$ of them were nurses), $8.3 \%$ of them were in the area of communication ( $6.1 \%$ were journalists), $1.5 \%$ were in the area of financial institutions, and $0.4 \%$ respectively were representatives from Agricultural firm and churches.

The results on the evaluation of training received show the perception of self-satisfaction among Butembo university graduates. Findings indicate that graduates strongly agree that what they learned in college help them in their professions with the mean of 4.23, they agree (mean=3.67) that there are signs of higher learning institution and universities success in Butembo and surrounding, they agree (3.57) that Alumni who studied in Butembo and surroundings do not have jobs in their fields of training; they agree for the satisfaction of the training received with an average mean of 3.49 . Respondents partially agree that there are businesses created by graduates with a mean of 3.38 and 
partially agree that there are signs that show the failure of university education in Butembo and its surroundings with a mean of 2.67. This average is consistent with what these respondents give as an overall assessment of university education in Butembo and Surroundings, presenting a numerical average of 6.42 , giving the grade good with a standard deviation of 1.08. Based on the study results, the following recommendations were formulated:

- The finalists from higher education and university institutions in Butembo and the surrounding area should double their efforts to evolve from job seekers to job creators to develop the region and the country.

- The State should consider the existence of higher education and university establishments in Butembo and its surroundings and help them improve the quality of infrastructure, make scholarships available to teachers and students, and fund research. Also, create an environment conducive to investments that can increase jobs in favor of university graduates. Students should take their choice of orientation seriously to be of use to themselves and the community by putting into practice what they learn during training.

- Researchers should make the results of their work available to the community and other scientists for all purposes. Teachers should take their role as trainers seriously because parents and the community rely a lot on them by entrusting the students to them and engaging the finalists in the companies.

- Since university education aims to excellence, the results of this investigation show that Butembo university education and surroundings, all being on the right track, still has a lot to do. It would also be interesting to expand practical sessions and think about laboratories within establishments. Given the socio-economic context of the region, partnerships with foreign universities are to be encouraged.

\section{References}

AfDB et al. (2012), African Economic Outlook 2012: Promoting Youth Employment, OECD Publishing, Paris, https://doi.org/10.1787/aeo-2012-en.

Bonvin, F. (2019). QUALITE, EFFICACITE ET EQUITE :LES ENJEUX DU SYSTEME EDUCATIF SUISSE AU REGARD DE LA REDEFINITION DU CHAMP EDUCATIF AU NIVEAU INTERNATIONAL. L'éducation en débats: analyse comparée:: Education in debate: comparative analysis, 20-39.

Darra, M (2006). Productivity Improvements in Education: A Replay, European Research Studies Volume IX, Issue (3-4), pp 101-124.

Etshim, R. (2017). Collaboration between Higher Education and Labor Market in Kinshasa, DR Congo, Journal of International Education and Leadership, Volume 7 Issue 1, pp 1-17

Jafari Bouchra, A. Y. (2019). ELUCIDATION DU ROLE DE LA REPRESENTATION MATRICIELLE A L'AIDE DE LA CONSTRUCTION D'UNE MATRICE DE LA QUALITE DE L'ENSEIGNEMENT SUPERIEUR. Revue Marocaine de recherche en management et marketing, 2747.

Kabange, J. K. (2014). LOI-CADRE No 14/004 DU 11 FEVRIER 2014 DE L'ENSEIGNEMENT NATIONAL. Kinshasa: Cabinet du President de la Republique. 
Kasai K. L., N. L. (1998). Structure de la population estudiantine de l'ISP / Bukavu (1565-1995). CAHIERS DU CERUKI, 70-85.

Kivete, M. (2013). Reflexion sur la pertinence de l'enseignement superieur et universitaire de Butembo et ses Environs. Cas de la faculte des sciences economiques. ANALES DE L'I.S.P. MUHANGI A BUTEMBO, 5-27.

Matumaini, K. (2015). La fabrication et la commercialisation des marmites en ville de Butembo. Butembo: Inedit (ISP Muhangi).

Kamal Zouhri, S. E. (2016). Indicateurs d'évaluation de l'efficacité de l'enseignement dans le système universitaire marocain. Revue Marocaine de recherche en management et marketing, 349-360.

Modisaotsile, B.M. 2012. The failing standard of basic education in South Africa. AISA Policy brief. 72: March 2012.

Neumann T. (2017). The implications for the educational effectiveness of online master's degree programs.

OECD (2004). Education at a Glance 2004: OECD Indicators. Paris: Centre for Educational Research and Innovation, OECD.

OECD (2005). Education at a Glance 2005: OECD Indicators. Paris: Centre for Educational Research and Innovation, OECD.

Perrenoud, P. (2005). Développer des compétences, mission centrale ou marginale de l'université ? Génève: pdf.

Perrichot, R. (2018, Avril 12). Emploi : les métiers et les secteurs qui recrutent le plus en 2018. Récupéré sur REGIOnsJOB: https://www.regionsjob.com/actualites/ces-10-secteurs-dactivite-et-10metiers-qui-recrutent-a-tout-va-en-2018.html 